\title{
Erosive Potential of Three Different Beverages on Human Enamel and Dentine: An in vitro Study
}

\author{
CRISTIAN FUNIERU ${ }^{1}$, IOANA ANDRADA OBAGIU ${ }^{2}$, ROXANA OANCEA ${ }^{3 *}$, \\ BOGDAN DOBRICA ${ }^{4}$, RUXANDRA IONELA SFEATCU ${ }^{5}$, MIHNEA IOAN NICOLESCU ${ }^{6}$ \\ ${ }^{1}$ Carol Davila University of Medicine and Pharmacy, Faculty of Dental Medicine, Preventive Dentistry Department, 2-4 Eforie Str., \\ 050037, Bucharest, Romania \\ ${ }^{2}$ Dental Hospital România, 5 Racari Str., 031827, Bucharest, Romania \\ ${ }^{3}$ Victor Babes University of Medicine and Pharmacy, Faculty of Dental Medicine, Preventive Dentistry, Community and Oral Health \\ Department, 14A Splaiul Tudor Vladimirescu Av., 300173, Timisaoara, Romania \\ ${ }^{4}$ University of Bucharest, Faculty of Physics, 405 Atomistilor Str., 077125 Magurele, Romania \\ ${ }^{5}$ Carol Davila University of Medicine and Pharmacy, Faculty of Dental Medicine, Oral Health and Community Dentistry Department, 2- \\ 4 Eforie Str., 050037, Bucharest, Romania \\ ${ }^{6}$ Carol Davila University of Medicine and Pharmacy, Faculty of Dental Medicine, Histology Department, 8 Eroii Sanitari Av., 050474, \\ Bucharest, Romania
}

\begin{abstract}
A lot of studies reported a strong association between beverages consumption and dental erosion. The erosive effect of soft drinks depends on their composition, $\mathrm{pH}$ or on individual salivary flow rate. The main methods used for analysing this effect are: profilometry, which measuring the enamel loss during demineralisation, and microscopic analysis. This study is an experiment developed in order to analyse the human enamel and dentine surfaces previously exposed to beverages. The main results of this study showed that soft drinks which contain both, sugar and phosphoric acid have the greatest erosive potential on human enamel and dentine compared to other beverages.
\end{abstract}

Keywords: erosive effect, beverages, dental enamel, dentine

\section{Introduction}

Unlike tooth decay, dental erosion is a chronic and localized loss of tooth structure due to a chemical process which has no connection with any bacterial involvement [1]. The process is linked to acidic foods and soft drinks consumption. This food habit (beverage consumption) seems to had grown very much in the past years (almost 3.6\% per year) due to an enormous amount of beverages produced for world consumption (231 l per capita per year), $12.5 \%$ of them being carbonated soft drinks [2]. This can be a cause for dental erosion prevalence growing, especially in children and adolescents [3]. However, the beverage consumption is not the only risk factor for dental erosion, a lot of other issues being involved in its development such as regurgitation or frequent involuntary vomiting, chewable acidic medication (vitamin $\mathrm{C}$ or aspirin), drugs consumption such as ecstasy, low saliva flow rate or impairments of its buffering capacity, mouth breathing etc. [4,5].

A lot of studies show a direct link between dental erosion and beverage consumption, the main factor being represented by their $p \mathrm{H}$ values. The $p \mathrm{H}$ can have different values, for example 2.7 for Coke/Pepsi and 4.2 for the bottled black tea [4]. Two methods have been previously used in in vitro experiments for detecting the soft drinks erosive effect: profilometry [6,7] and microscopic analysis [5,8-11]; the first one measures the enamel loss and the second analysis the enamel surface previously exposed to beverages. However, very few studies have analysed in detail the exposed enamel surfaces using the atomic-force microscope.

The major goal of this study is to compare the erosive effects of three kinds of beverages on human enamel and dentine surfaces and find how these surfaces microscopically look like after four hours of beverage exposure. 


\section{Materials and methods}

\section{Preparation of tooth samples (enamel and dentine)}

25 human caries free teeth from permanent dentition (Figure 1) were used for this experiment. The teeth were immersed in $96^{\circ}$ alcohol for 1 hour right after they were extracted. Afterwards, calculus, stains and remaining periodontal tissues were removed using a Kavo ultrasonic scaler, followed by a professional cleaning (Figure $2 \mathrm{a}$ and $\mathrm{b}$ ). Next, the teeth were immersed for $24 \mathrm{~h}$ in a $1 \%$ solution of sodium hypochlorite. The teeth have been cut into 24 enamel and dentine blocks, every block measuring between 1.5 and $2 \mathrm{~mm}$ in height (Figure 3a). Afterwards, they were in order cleaned, brushed and treated with hydrogen peroxide, alcohol and neophaline.

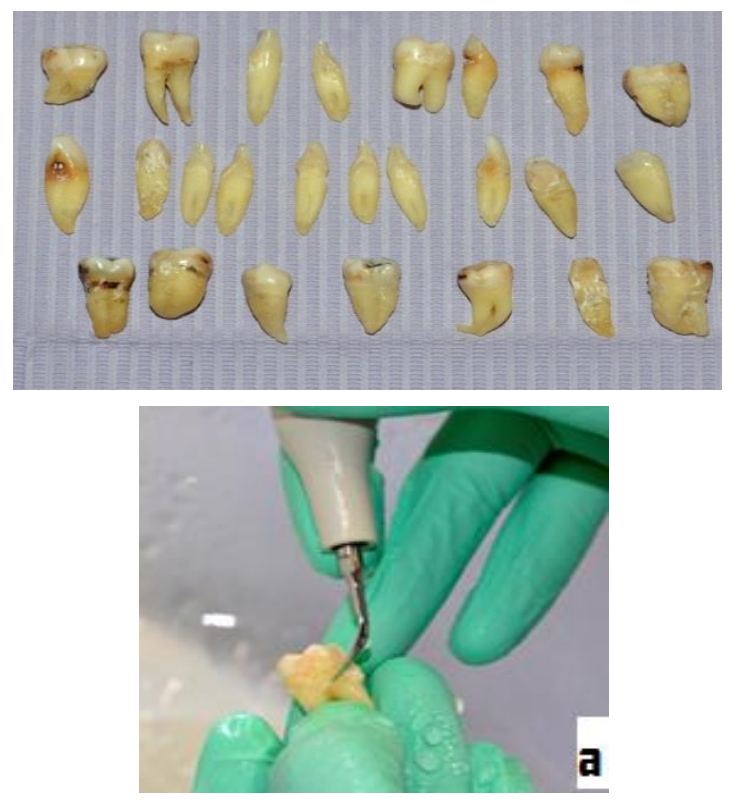

Figure 1. The 25 human teeth used in the experiment

Figure 2. Stains removal using Kavo ultrasonic scaler (a) followed by a professional cleaning (b)

\section{Preparing beverage solutions and blocks demineralisation}

We chose three different soft drinks: one with carbonic and phosphoric acids and sugar (Coca Cola, beverage no. 1), one with carbonic and phosphoric acids and no sugar (Coca Cola zero, beverage no. 2), and one with sugar only (Cappy Orange, beverage no. 3). 20 enamel/dentine blocks were randomly chosen for this experiment from a total of $25.12,5 \mathrm{ml}$ of each beverage were added from the first time in three plastic containers, along with 5 dental blocks each. The same quantity of beverage was added at every $30 \mathrm{~min}$. After four hours, every plastic container had 5 blocks in $100 \mathrm{ml}$ of beverage. Every block was then washed with clean water, dried and ready for the microscopic analysis. 5 blocks were kept in a control group.

\section{Microscopic analyses and data processing}

The enamel and dentine blocks were fixed initially with special clay (Figure $3 b$ ) and then analysed with Ntegra Prima atomic-force microscope. The microscopic images were analysed and 3D processed using the 2.2.0 version of NT-MDT Image Analysis software and data were statistically analysed using the 16.0 demo version of the SPSS IBM processor. 
Figure 3. The enamel and dentine blocks (a) and one block stuck into clay and ready for the microscopic analysis (b)

\section{Results and discussions}

The dental blocks (enamel and dentine) exposed to beverages that contains phosphoric acid display very rough surfaces. This can be observed on the $3 \mathrm{~d}$ reconstruction images (Figure $4 \mathrm{a}$ ) provided by the NT-MDT Image Analysis software. The dentine surfaces show highly mineralized areas around the dentinal tubules (Figure 4b).
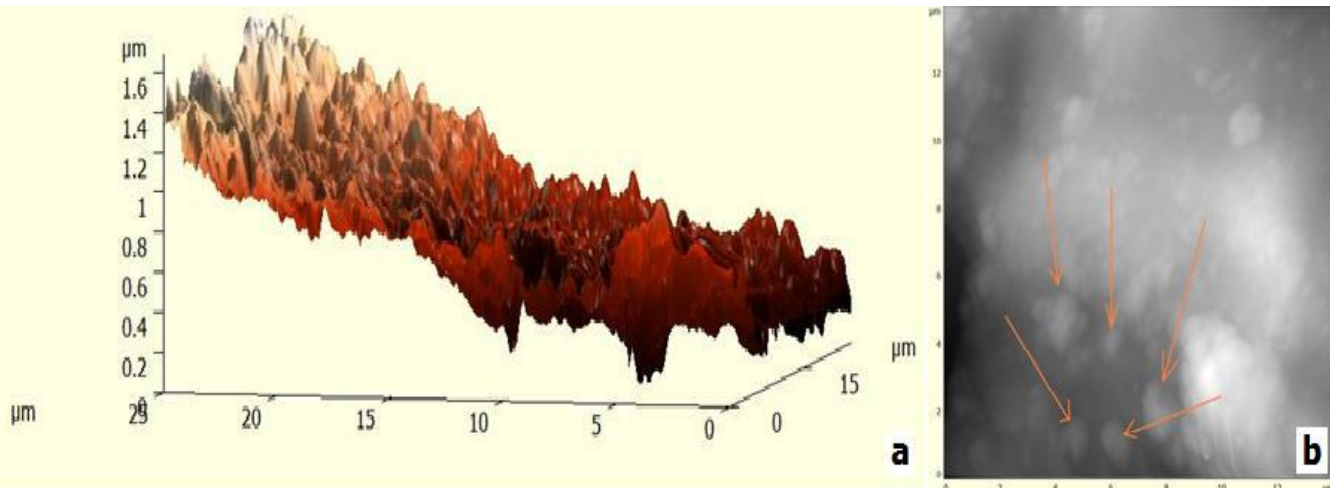

Figure 4. Electron microscopy images of an enamel-dentin block previously exposed to beverage no. 1 (Coca Cola): enamel surface - an image of $3 \mathrm{~d}$ software reconstruction (a) and dentine surface - rounded and hiper-mineralized areas around the dentin tubules (arrows) (b)

We calculated medium roughness on three different areas of every surface, using NT-MDT Image Analysis software (Table 1). Afterward, the T paired test was performed to compare the roughness of all kinds of possible surfaces (Table 2):

Table 1. The roughness medium values $(\mathrm{nm})$ for dental blocks previously exposed to beverages

\begin{tabular}{|c|c|c|c|c|}
\hline & Control blocks & $\begin{array}{c}\text { Blocks exposed to } \\
\text { beverage no. } 1\end{array}$ & $\begin{array}{c}\text { Blocks exposed to } \\
\text { beverage no. } 2\end{array}$ & $\begin{array}{c}\text { Blocks exposed to } \\
\text { beverage no. } 3\end{array}$ \\
\hline \multirow{15}{*}{$\begin{array}{l}\text { Roughness } \\
\text { medium values } \\
\quad(\mathrm{nm})\end{array}$} & 710.5 & 762.5 & 1241 & 1025 \\
\hline & 605 & 1340 & 1306 & 711 \\
\hline & 885 & 899 & 911 & 679 \\
\hline & 1104 & 1106 & 856 & 1008.5 \\
\hline & 910 & 1489 & 1103 & 992 \\
\hline & 917 & 877 & 999 & 904 \\
\hline & 890 & 999.5 & 889 & 841 \\
\hline & 701 & 1307 & 1012 & 709.5 \\
\hline & 695 & 1201 & 1107 & 1002 \\
\hline & 688.5 & 1189 & 1305 & 1308 \\
\hline & 886 & 1003 & 789 & 708 \\
\hline & 1004 & 979.5 & 894.5 & 899 \\
\hline & 1205 & 887 & 996 & 911 \\
\hline & 1013 & 1310 & 1001 & 1019 \\
\hline & 701 & 1235.5 & 776.5 & 883 \\
\hline Mean & 861 & 1106 & 1012 & 907 \\
\hline
\end{tabular}


Table 2. The statistical compilations developed for comparing the erosive effects of beverages

\begin{tabular}{|c|c|c|c|c|c|}
\hline Surfaces compared & Mean & Std. Deviation & $\begin{array}{c}\text { Std. Error } \\
\text { (mean) }\end{array}$ & T & p \\
\hline Control - beverage no. 1 & -244.66667 & 311.34711 & 80.38948 & -3.044 & $0.009^{*}$ \\
\hline Control - beverage no. 2 & -151.40000 & 299.11985 & 77.23241 & -1.960 & 0.070 \\
\hline Control - beverage no. 3 & -45.66667 & 236.05710 & 60.94968 & 1.494 & 0.466 \\
\hline Beverage no. 1 - beverage no. 2 & 93.26667 & 241.83132 & 62.44058 & -0.749 & 0.157 \\
\hline Beverage no. 1 - beverage no. 3 & 199.00000 & 255.66238 & 66.01174 & 3.015 & $0.009^{*}$ \\
\hline Beverage no. 2 - beverage no. 3 & 105.73333 & 181.60611 & 46.89050 & 2.255 & $0.041^{*}$ \\
\hline
\end{tabular}

*Statistically representative values $(\mathrm{p}<0.05)$

Summarizing all the results exposed above, it seems like the beverage which contains both phosphoric acid and sugar produced the roughest enamel/dentine surfaces compared to control group, the result being statistically confirmed $(\mathrm{p}<0.05)$. Moreover, this beverage produces more damage to the dental blocks rather the other two beverages (with phosphoric acid and no sugar and with sugar only) (p $<0.05)$. Using the $3 \mathrm{~d}$ reconstruction tool from the NT-MDT Image Analysis software we can say how the enamel surfaces look like after they were previously exposed to beverages (Figure 4a). The dentine surface displayed an interesting aspect: after the surfaces were exposed to beverages and demineralized, it seems like new hiper-mineralized areas appeared around the dentine tubules. They can be observed as white rounded shapes (Figure $4 \mathrm{~b}$ - arrows).

Most studies show that the erosive effect grows when the $\mathrm{pH}$ is more acid $[6,12]$, as well the calcium and phosphorus ions concentrations will be strongly decreased. Some studies proved this mechanism for beverages like Pepsi, Coca Cola, and lemon juice [13-15]. The time of exposure is another parameter that increases the demineralisation effect. Jager et al. showed in their study that apple juice or Coca Cola light produce on average $0.01 \mathrm{mmol} / \mathrm{L}$ calcium and phosphate loss [16]. A lot of studies used a time of beverage exposure between $3 \mathrm{~min}$ and one hour which is less than we used $(4 \mathrm{~h})$. This could be one of the reasons for finding very rough enamel and dentine surfaces. We found out that the beverage no. 1 (Coca Cola) had the most erosive effect and produced the roughest dental surfaces. The same result was obtained for example by Barac et al. in their study [7]. However, it is very clear why soft drinks with different concentration of phosphoric acid or sugar have different erosive effects but Murrell et al. found that the same beverage produced or drunk in different countries has different demineralisation intensity. They thought for example, that the beverages from the US and UK are different from this point of view [10]. Thus, the composition of beverages must be improved in order to minimize the erosive effect by adding calcium [10] or different metallic ions like $\mathrm{Fe}^{2+}, \mathrm{Cu}^{2+}, \mathrm{Zn}^{2+}, \mathrm{Mn}^{2+}[12]$.

Our study has also some limitations, the first being the small number of dental blocks used in the protocol. The study analysed the erosive potential of beverages only as an experiment. It cannot reproduce exactly the same conditions from the oral environment such as saliva secretion and its buffer capacity, so the effect of beverages can be somehow overestimated in this study.

\section{Conclusions}

The main finding of our study is beverages that contain both sugar and phosphoric acid seem to develop the most dangerous erosive effect on human enamel and dentine. In order to prevent this, the beverages should contain various metallic ions that would raise the $\mathrm{pH}$, and the patients should also ask their dentists about prophylactic measures such as daily tooth brushing or using fluoride gel and mouthwash. The atomic-force microscope analysis followed by the image processing using NT-MDT Image Analysis software was an excellent method for building a real picture of how enamel or dentine surfaces look like after they were previously exposed to beverages. 


\section{References}

1.JAMEEL, R.A., KHAN, S.S., ABDUL RAHIM, Z.H., BAKRI, M.M., SIDDIQUI, S., Journal of Pakistan Medical Association, 66, 2016, p 843

2.NEVES, M.F., TROMBIN, V.G., LOPES, F.F., KALAKI, R., MILAN, P., World Consumption of Beverages (Chapter: The orange juice business), Wageningen Academic Publishers, Wageningen, Netherlands, 2011, p. 118

3.NUNN, J.H., GORDON, P.H., MORRIS, A.J., PINE, C.M., WALKER, A., International Journal of Paediatric Dentistry, 13, no. 98, 2003, p. 98

4.YANG-FANG, R., Registered Dental Hygienist, 33, no. 88, 2011, p. 76

5.EHLEN, L.A., MARSHALL, T.A., QIAN, F., WEFEL, J.S., WARREN, J.J., Nutrition Research, 28, no. 5,2008 , p. 299

6.FUJII, M., KITASAKO, Y., SADR, A., TAGAMI, J., Dental Materials Journal, 30, no. 3, 2011, p. 404

7.BARAC, R., GASIC, J., TRUTIC, N., SUNARIC, S., POPOVIC, J., DJEKIC, P., RADENKOVIC, G., MITIC, A., Medical Principles and Practice, 24, no. 5, 2015, p. 451

8.POGGiO, C., CECI, M., BElTRAMI, R., LOMBARDINI, M., COlOMBO, M., Annali di Stomatologia, 5, no. 3, 2014, p. 98

9.BORJIAN, A., FERRARI, C.C.F., ANOUF. A., TOUYZ, L.Y.G., International Journal of Dentistry, 20, 2010, p. 1

10.MURRELL, S., MARSHALL, T.A., MOYNIHAN, P.J., QIAN, F., WEFEL, J.S., Journal of Dentistry, 38, no. 4, 2010, p. 284

11.WANG, Y.L., CHANG, C.C., CHI, C.W., CHANG, H.H., CHIANG, Y.C., CHUANG, Y.C., CHANG, H.H., HUANG, G.F., LIAO, Y.S., LIN, C.P., Journal of Formosan Medical Association, 113, 2014, p. 850

12.DE CARVALHO SALES-PERES, S.H., MAGALHAES, A.C., DE ANDRADE MOREIRA MACHADO, M.A., BUZALAF, M.A., European Journal of Dentistry, 1, 2007, p. 10

13.BALAN, A., ANDRIAN, S., SAVIN, C., SANDU, A-V., PETCU, A., STOLERIU, S., Rev Chim., 66, no. 4, 2015, p.562

14.ARNĂUŢEANU, C., STOLERIU, S., IOVAN, G., SANDU, A.V., ILIESCU, A.A., ANDRIAN, S., Rev Chim., 64, no. 11, 2013, 1335

15.STOLERIU, S., IOVAN, G., GEORGESCU, A., SANDU, A.V., ROŞCA, M., ANDRIAN, S., Rev Chim., 63, no. 1, 2012, p. 68

16.JAGER, D.H.J., VIEIRA, A.M., RUBEN, J.L., HUYSMANS, M.C.D.N.J.M, Journal of Dentistry, 40, no. 12,2012 , p. 1103

Manuscript received: 14.10 .2019 